\title{
Reaching all learners through their phones and universal design for learning
}

THOMAS J. TOBIN*

Learning Design, Development, \& Innovation (LDDI), University of Wisconsin-Madison, Madison, WI, USA

(Received: November 5, 2017; revised manuscript received: March 6, 2018; second revised manuscript received: March 23, 2019; accepted: March 25, 2019)

\begin{abstract}
To help make educational materials and practices inclusive and useful for all learners, this review article provides the history of the universal design for learning (UDL) framework by defining it in its educational context and by showing how it has been adopted in K-12 and higher education institutions across North America. It reframes UDL as a strategy for reaching adult learners on their mobile devices, and radically reflects on how faculty members and course designers can adopt UDL in order to create learning interactions that provide students with more time for study and practice in their busy days. To this end, the author argues that we should broaden our course-access-design focus away from learners with disabilities and toward a larger ease-of-use/general-inclusion framework. Going through this article, we will be able to help our faculty colleagues to incorporate UDL elements into their courses, design/retrofit existing course components using UDL principles, and expand our institution's use of UDL elements beyond the legally required minimum. This article posits diversity in its most inclusive form: instead of relying solely on providing accommodation services to learners with disabilities - which is most often a last-minute, ad-hoc, reactive process - adopting UDL as part of an institution's culture of course design, teaching practices, and support services allows all learners to benefit, regardless of their place on the ability spectrum.
\end{abstract}

Keywords: universal design for learning; accessibility; inclusion; diversity; accommodation

\section{THE ROOTS OF UNIVERSAL DESIGN FOR LEARNING (UDL)}

In architecture, universal design (UD) is "the design of products, environments, and communication to be usable by all people, to the greatest extent possible, without adaptation or specialized design" (Institute for Human Centered Design, 2017, para 1). We can trace the formal concept of UD back to architect Ron Mace (Schwab, 2015). Mace had polio during his childhood and used a wheelchair to get around. He recognized in the 1950s that the US population was aging. He foresaw that people who were no longer able to navigate stairs or small bathrooms would have to move out of their unusable homes and into nursing facilities or the homes of relatives. Mace argued that if architects designed homes to be "usable by everyone to the greatest extent possible" from the beginning, then more people could continue to stay at home as they aged (Gaylord, Johnson, Lehr, Bremer, \& Hasazi, 2004, p. 4).

The concept of UD makes intuitive sense. Designing supermarkets to have sliding doors with electronic sensors allows more people to enter and exit the store with ease: people pushing shopping carts as well as people in wheelchairs alike. By adding closed captions to television programs, more people can enjoy them: viewers who are learning the language, who want to keep up with unfamiliar accents, or who have hearing impairments. All of these design elements in the built environment are simple, unobtrusive, and make our lives easier.

In 1990, the US Congress amended Section 508 of the Rehabilitation Act to include all communication and information technology. This meant that phone lines, television shows, movies, the Internet, and information kiosks must be accessible. This extension of UD principles from the physical environment to the digital one was a major step toward the eventual creation of UDL.

In short, UD became a mental framework that supports the civil rights of all citizens. It reduces the need for people with disabilities to have to ask for special treatment through accommodations (making one change, one time, for one person), instead promoting a more holistic existence through UD that is aimed at making life easier for everyone. The work that Ron Mace initiated continues today at the Center for Universal Design (2008) at North Carolina State University. The Center for UD developed seven principles to guide the designs of environments, products, and communications, as shown in Table 1 (Connell et al., 1997).

Over the years, these principles have guided architects and designers in the work they do, while also uniting people with various needs through equal access.

* Correspondence: Thomas J. Tobin, Learning Design, Development, \& Innovation (LDDI), University of Wisconsin-Madison, Madison, MI 53715, USA; Phone: +1 312810 0805; e-mail: dr.tobin@att.net

This is an open-access article distributed under the terms of the Creative Commons Attribution-NonCommercial 4.0 International License, which permits unrestricted use, distribution, and reproduction in any medium for non-commercial purposes, provided the original author and source are credited, a link to the CC License is provided, and changes - if any - are indicated. 
Table 1. The principles of Universal Design (Connell et al., 1997)

\begin{tabular}{|c|c|}
\hline Principle & Definition \\
\hline Equitable use & $\begin{array}{l}\text { The design is useful and marketable to } \\
\text { people with diverse abilities }\end{array}$ \\
\hline Flexibility in use & $\begin{array}{l}\text { The design accommodates a wide range } \\
\text { of individual preferences and abilities }\end{array}$ \\
\hline Simple and intuitive & $\begin{array}{l}\text { Use of the design is easy to understand, } \\
\text { regardless of the user's experience, } \\
\text { knowledge, language skills, or current } \\
\text { concentration level }\end{array}$ \\
\hline $\begin{array}{l}\text { Perceptible } \\
\text { information }\end{array}$ & $\begin{array}{l}\text { The design communicates necessary } \\
\text { information effectively to the user, } \\
\text { regardless of ambient conditions or the } \\
\text { user's sensory abilities }\end{array}$ \\
\hline Tolerance for error & $\begin{array}{l}\text { The design minimizes hazards and the } \\
\text { adverse consequences of accidental or } \\
\text { unintended actions }\end{array}$ \\
\hline Low physical effort & $\begin{array}{l}\text { The design can be used efficiently and } \\
\text { comfortably and with a minimum of } \\
\text { fatigue }\end{array}$ \\
\hline Size and space for use & $\begin{array}{l}\text { Appropriate size and space is provided } \\
\text { for approach, reach, manipulation, and } \\
\text { use regardless of user's body size, } \\
\text { posture, or mobility }\end{array}$ \\
\hline
\end{tabular}

\section{UDL started in elementary and secondary education}

The transition from UD in the built world to UDL in the sphere of educational interactions was a gradual one that started in the K-12 world. If students cannot get access to school buildings, then they are at a disadvantage compared to their peers. Similarly, if students cannot participate in the curriculum or methods of instruction being used, then they are also at a disadvantage. UDL examines what happens once students get through those school doors. How can we remove the barriers in the learning environment?

UDL began in the early 1990s, when David Rose and his colleagues at the Center for Applied Special Technology (CAST) argued that UDL "puts the tag 'disabled' where it belongs - on the curriculum, not the learner. The curriculum is disabled when it does not meet the needs of diverse learners" (Council for Exceptional Children, 2011, para 5). The scientists at CAST used neuroscience as the basis of the UDL framework, extending the UD principles that had been created to guide the design of things (e.g., buildings and products) out into the design of social interactions (e.g., human learning environments).
CAST began by examining the diversity and academic success of students in US public elementary and secondary schools in order to address a number of questions related to academic success. Was it an indication of students' ability when some seemed unable to pay attention to their teachers after fifteen minutes of lecturing? Were students whose first language was not English being punished unfairly because they couldn't take notes fast enough? Why were students who did not have access to computers weaker than their peers on writing concepts? CAST looked holistically at student demographics, methods of instruction, and curriculum design, initially seeking a frame that would fit all of these differences into one instructional method. Their finding, however, was that variability is the norm: no two students learn alike, regardless of ability. Curriculum design at the time was largely monolithic, forcing all students to receive information and demonstrate skills in only one way. David Gordon writes about the need to recognize and design for learner variability:

Options are essential to learning, because no single way of presenting information, no single way of responding to information, and no single way of engaging students will work across the diversity of students that populate our classrooms. Alternatives reduce barriers to learning for students with disabilities while enhancing learning opportunities for everyone. (Council for Exceptional Children, 2011, para 3)

CAST set about translating Ron Mace's principles of UD for the built environment into ways to design the interactions in elementary and secondary education systems. Their resulting framework is called UDL and maps the seven areas of UD into three brain-based information networks specific to learning and neurological processing, as shown in Table 2.

It is important to note that, in the UDL framework, there is no requirement that information be presented in all of its different possible permutations, or in one unique way per student, like the theory of differentiated instruction (DI) asks for, in which teachers identify the strengths of their learners and then customize instruction to play to those strengths (Tomlinson, 1999). Rather, UDL posits that designing for learner variability ahead of time - before instructors even know their students yet - is the most effective way to reduce individual accommodation needs (Tobin \& Behling, 2018, p. 25). In other words, offering students choices in how to recognize, engage with, and report back the information that they learned increases the opportunities that instructors can connect with their students and their learning needs.

Table 2. Three brain networks in universal design for learning (CAST, 2016)

\begin{tabular}{lll}
\hline Brain network & \multicolumn{1}{c}{ Question } & \multicolumn{1}{c}{ Solution } \\
\hline Recognition & The what of learning & Present information in multiple ways \\
& How do we gather information? & \\
Strategic & $\begin{array}{l}\text { The how of learning } \\
\text { How do we express our ideas? }\end{array}$ & Differentiate the ways that students can express what they know \\
Affective & $\begin{array}{l}\text { The why of learning } \\
\text { How do we motivate learners? }\end{array}$ & $\begin{array}{l}\text { Find a way to connect with student interests. Provide multiple methods of engaging } \\
\text { with the material }\end{array}$ \\
\hline
\end{tabular}




\section{UDL IN HIGHER EDUCATION}

In North America and Europe, we in higher education, have not been as quick to adopt UDL as our colleagues in the elementary and secondary settings. UDL in higher education began in earnest in the early 2000s, when the Office of Postsecondary Education (OPE) in the US Department of Education created grants for colleges and universities seeking to bring the concept to higher education (Office of Special Education Programs [OSEP], 2004). The OPE saw the positive effects of inclusive-design efforts in elementary and secondary education and recognized that as students in those schools graduated and transitioned to college, they would expect the same breadth of learning opportunities as they had previously enjoyed.

Many of those who applied for and received the OPE grants were members of disability service offices in colleges and universities - those most likely to be part of conversations about inclusive education and to know about the work of CAST. They saw UDL as a built-in service to improve the educational experiences of both the students with disabilities with whom they worked, those who chose not to disclose disabilities, or who had yet to come to their offices.

The OPE grants spurred work to figure out how to bring inclusive design to college and university campuses, given the differences among elementary, secondary, and higher education. Grant-funded researchers recognized the difficulty in mandating any particular training or implementation scheme in college and university settings. For this reason, most grantees created implementation frameworks not through a disability services lens, but rather through the diversity lens that Ron Mace established years ago for UD. The goal of the OPE grants was to increase awareness about inclusive design in higher education. Different OPE grant institutions created or adopted different definitions and approaches to accessibility, all based on UD. Each of these definitions, approaches, and strategies differs slightly in its approach and scope. Some institutions simply adopted the core principles of UD as is from the Center for UD. The University of Wisconsin system used the UD architectural principles to increase access for students with disabilities. They focused on using UD to increase the accessibility and usability of the educational technology that the university was using at the time.

At Temple University, the OPE grant project included UDL in the orientations for new faculty and staff members, who were then asked to incorporate the principles in their courses and student interactions. The University of Iowa conducted a campus UDL needs assessment and developed a university-wide policy focusing on the goal of giving universal access to learning interactions. The University of Hawaii combined UDL with multiculturalism and mentoring in an effort to get campus staffers and faculty members to support diverse learners better. Colorado State University's twice-funded project focused on supporting faculty members in adding UDL strategies to the materials that they created for their courses (OSEP, 2004).

The OPE grants resulted in a diverse group of researchers trying to figure out how to best introduce the concept of inclusive design into the college environment. How do colleges and universities adopt a set of design principles for learners' interactions with materials, each other, their instructors, and the wider world that positively affects the greatest number of students from the start? (CAST, 2014). Colleges and universities are increasingly broadening the scope of their efforts to address student diversity across an increasing number of identity spaces, including ethnicity, socioeconomic status, gender and sexual identity, and currently the ability spectrum. For example, Professor Lyman Dukes at the University of South Florida at St. Petersburg worked with his Accessibility Committee to study the impact of captioning on all students in a Law and Business course. He recorded his lectures and gathered all of the multimedia materials that he used throughout the semester. He then captioned all of his videos and posted them online for his students to access. At the end of the semester, he surveyed his students about their attitudes toward captioning. Ninety-four percent of his students reported that the ability to turn on the captions while watching his videos was helpful and $92 \%$ of them actively used the captions. Only $1 \%$ of his students reported working with the university's disability services office, although $13 \%$ stated that they identified as having a disability and had not yet registered. Professor Dukes' small-scale study is an example of the individual approach that many faculty members have taken toward implementing UDL principles in their courses (Dukes, 2014).

Some institutions have entire departments that have embraced UDL. In Boston, Suffolk University's Mathematics Department faculty members have reconsidered the way that they offer instruction to their students. After dealing with inaccessible textbooks and an increase in the number of students who struggled to pass first-level math courses, the department got together and focused on addressing learner variability. They now offer a math course designed for students who do not love math, where learners apply math concepts to real-life situations (Tobin \& Behling, 2018, p. 36).

At the University of New Hampshire, the Occupational Therapy (OT) Department ran a small study a few years ago implementing UDL strategies (specifically sharing videos of OT movements) into one section of a core course, using another section as a control group. After observing the grade improvement and overall students' understanding of OT increase, the department decided to adopt UDL as a group and infuse those strategies into all of their courses. They try to add at least onenew strategy each time a course is taught, evaluating its effectiveness as a department at the end of the semester.

Few institutions have yet adopted the concept of UDL as an entire institution. Rather, while many agree that it is a good idea and actively support grass-roots efforts on the part of their instructors, institutions tend to devote their resources elsewhere. My aim in this review article is to provide reasons, research, tools, and arguments for moving beyond the individual-adoption stage and moving toward campuswide UDL implementation.

\section{EMOTIONAL VALENCE AND ACCOMMODATIONS}

Most of us have had the experience of receiving accommodation requests from students with disabilities. Our 
emotional response to UDL gets inflected with the valence from our experiences making disability accommodations. Valence refers to our emotional coloring for "events, objects, and situations.... [T]hey may possess positive or negative valence; that is, they may possess intrinsic attractiveness or aversiveness" (Frijda, 1986, p. 207).

Researchers have been studying for decades how we, in higher education, respond to students with learning challenges. In multiple large research studies since 1981, the emotional valence associated with accommodations is almost uniformly negative (see Benham, 1997; Bento, 1996; Bigaj, Shaw, \& McGuire, 1999; Cook, Rumrill, \& Tankersley, 2009; Fichten, 1986; Fonosch \& Schwab, 1981; Houck, Asselin, Troutman, \& Arrington, 1992; Lombardi \& Murray, 2011; Murray, Lombardi, \& Wren, 2011; Murray, Lombardi, Wren, \& Keys, 2009; Nelson, Dodd, \& Smith, 1990; Zhang et al., 2010).

In many faculty members' minds, the fact that one must accommodate learners with disabilities brings up feelings of uncertainty, confusion, annoyance, and even anger (Lombardi, Murray, \& Gerdes, 2011). In 2017, Michael Schlesinger, a professor of atmospheric sciences at the University of Illinois at Urbana-Champaign, was placed on paid administrative leave because he refused to provide electronic copies of lecture slides in advance of class sessions for a student who had a documented disability accommodation. Schlesinger argued that

based on my experience of providing all my students my lecture slides after each lecture for most if not all of the 16 times I have taught this course, I knew that one-third of my class would cease coming to my lectures if I provided them my lecture slides electronically. And their ceasing to attend my lectures would lower their course grades. (Flaherty, 2017)

The professor derided the disability services staff member who notified him about the student's accommodation, writing that "although you have a doctorate, I doubt that you teach. Although you have a doctorate, I doubt that you do research," and saying that he would "fight for a more balanced approach to assisting disabled students, an approach that does not disadvantage non-disabled students" (Flaherty, 2017).

Thankfully, most of us do not react as extremely. Regardless of whether we act consciously on negative emotions, however, they ground our approach to learners with disabilities. In Reach Everyone, Teach Everyone, Kirsten Behling and the author share exemplars of the feedback that we encountered in the research literature and in interviews with faculty members and staffers throughout North America.

- "I don't have time to do all that work if it benefits just a few students with disabilities."

- "My institution doesn't have a captioning service. I'd have to do it all myself, and I have a lot of videos."

- "I think at least a few of my students are trying to game the system by claiming to have disabilities."

- "I know I should follow the law, but no one at my institution is enforcing it."

- "I haven't had a student with a disability for years. I will just wait until I get an accommodation request."
- "I've had a number of students come to me with 'learning disabilities,' but they don't seem to be disabled when I interact with them in my courses." (Tobin \& Behling, 2018, p. 4)

In all of these scenarios, the contrary is actually so. Sam Johnston, a research scientist at CAST, says that "we want a situation that is good for everybody. Part of it is thinking about what has to happen at the level of design that makes accommodation less necessary" (personal communication, November 15, 2013). Johnston means that by adopting UDL principles in our course design, we greatly reduce the need for specific accommodation requests.

\section{FIRST STEPS OF UDL}

Most of our existing college and university training programs and advocacy for adopting UDL stand poor chances of being effective, due to the negative emotional valence associated with making disability accommodations - even though UDL is not a means of granting individual disability accommodations (making one change, one time, to help one person). Despite this, our collective experience of making accommodations colors our response to a term that we think is associated with the same subject: learners with disabilities.

We react for many reasons. Applying UDL can be expensive and resource intensive. It takes design-level thinking, often beyond our current scope of subject expertise. UDL is not perceived as being for everyone - just for people with disabilities. The work we put into UDL is perceived as benefiting a small slice of our learners, so why not just wait until we get accommodation requests?

We must first uncouple UDL from the negative emotional valence of people's experiences with accommodation requests. For that, we propose two reframing statements that form the core principles of this review article. First, our students today are not like our students even 15 years ago. Second, our faculty members are not like their counterparts from the past, either.

\section{UDL is not just faculty members' job}

We should move the focus away from training only faculty members about UDL. Let us train the people who support them: IT departments, teaching-and-learning centers, mediaservices areas, academic-department staff, and the help desk. There is near consensus that institutions are responsible for providing education to the broadest audience of learners (Rapp \& Arndt, 2012). Frequently, we leave inclusion to the office of disability services or to individual faculty members. UDL training courses increase faculty members' confidence in working with students across the ability spectrum (Murray et al., 2011), but the highereducation UDL adoption rate hovers around $10 \%$ of faculty members (cf. Murray et al., 2009). Why? Faculty members do not do what they used to.

Over the past three decades, the role of faculty members has become increasingly atomized. Included in their primary duties, faculty members in 1985 were expected to design 
their course structure, create individual syllabi, pull together ancillary materials (e.g., prof packs, transparencies, and vendor-produced VHS tapes), teach course sessions, grade student work, and hold office hours.

Today, faculty members are still responsible for content expertise. However, much of what used to be individual faculty members' job is now the responsibility of the whole faculty (e.g., agreeing on common syllabi, reading lists, and texts) or support staff (e.g., creating videos, multimedia, and LMS content). Often, course content and interactions are designed by a team: the faculty member, an instructional designer, a media specialist, an IT coder, and others throughout the institution, such as librarians and visual artists.

UDL training, therefore, should focus on the people who actually put together the interactions for learners, and here we are referring not only to designing courses, but to designing the interactions that students have with our application processes, registrar's offices, tutoring services, and other touch-points common to the higher-education experience. For all types of interactions, we can apply UDL principles to make it easier for everyone to engage with them. Implementing UDL principles across an institution requires leadership support and resources. As Candyce Rennegarbe at Tacoma Community College reports, the investment is worth it:

By far, strong administrative support is the most important element. Our Vice President of Academic and Student Affairs has supported this project with funding and personal support since we started. He has used Achieving the Dream [program] funds and reserve funds; no major grant funding has been accessed to fund this project. We give release time to a faculty member to be the project manager in an affordable way to make sure there is sustained leadership....

We have also secured stipends for faculty members and mentors and have involved the instructional research department from the beginning. We have a strong crossdisciplinary advisory team (Dean/VP of Instruction, Access Services, E-Learning, Developmental Studies, Professional Development, Student Services, Faculty), and strong support for building technology resources on campus. (Meyer, Rose, \& Gordon, 2014, p. 169)

This approach - training those who actually do the development work on materials and interactions on which UDL touches - results in greater levels of adoption of UDL across the institution (Meyer et al., 2014, pp. 172-173). The College Supporting Transition, Access, and Retention (STAR) consortium, for example, is a UDL success story. Colleges and universities across North Carolina used a federal grant in order to create a curriculum shared across campuses (College STAR, 2015). All participating campuses sent their support and design staff to UDL-training sessions; at present, all courses are created with UDL principles in mind.

This is the goal of UDL after all: to reduce barriers to learning for everyone. While we should keep learners with disabilities always in mind, we serve the broadest audience by situating UDL as a way to reach mobile learners through anytime, anywhere interactions, and we should train our support staff in UDL, so faculty members who want to innovate are automatically presented with UDL as just the way things are done at our institution.

\section{HOW TO REFRAME UDL FOR ADULT LEARNERS?}

We should also reframe UDL beyond a narrow disability services mindset and situate it in an emotionally neutral narrative with which we are all familiar: mobile learning. This helps us to address some key challenges in higher education. For example, in comparison with learners just 15 years ago, college students today are more likely to require remediation (Adams, 2015), more likely to have poor study and time-management skills (College Board, 2015), and less likely to have significant time for study outside of the classroom (College Board, 2015).

Many college students are adult learners with families and jobs - and little time for studying: "Adult learners are juggling family, work, and educational responsibilities. They don't do optional" (Mason, 2014, para 11). Even our 18- to 22-year-old students are often juggling work and study responsibilities. Today, the young, single college student who lives at home, takes a full load of courses, and focuses solely on his or her studies is, with few exceptions, a mythical creature.

On the other hand, a recent EDUCAUSE study shows that $86 \%$ of college students in North America own smartphones (Chen, Seilhamer, Bennett, \& Bauer, 2015). Couple this with busy lifestyles, adopting a mobile-friendly design framework like UDL fosters anytime, anywhere learning:

As an integral part of students' daily lives, mobile technology has changed how they communicate, gather information, allocate time and attention, and potentially how they learn .... Learners are no longer limited to the classroom's geographical boundaries; for example, they can now record raw observations and analyze data on location. Furthermore, mobile technology platforms let individuals discuss issues with their colleagues or classmates in the field. The ever-growing mobile landscape thus represents new opportunities for learners both inside and outside the classroom. (Chen et al., 2015)

The argument for adopting UDL has always been based on its benefits for all learners, and now we have a broad-benefit argument to make: UDL reaches out to learners on mobile devices and gives them more time for studying (Tobin, 2014, pp. 20-24). Giving learners with family, work, and service obligations just 20 more min in their busy days for learning and interacting can be the difference between struggling and keeping up with their studies.

Before we can dive in to practical applications about how best to apply UDL principles to our courses, programs, and institutions, we must first determine how to uncouple UDL from the negative emotional valence of people's experiences 
with requests for specific accommodations. For that, the author wants to posit two radical reflections on the nature of teaching and learning in higher education today: our students today are not like our students 25 years ago, and our faculty members are not like their counterparts from the past, either.

\section{Adults are mobile learners}

Young adults today are labeled the "digital generation" by scholars like Howard Gardner (Gardner \& Davis, 2013), Ian Jukes, and Ted McCain (Jukes, McCain, \& Crockett, 2010). Such futurists talk see the digital generation as somehow separate from the rest of us by dint of their use of technology. "For Digital Natives, 'research' is more likely to mean a Google search than a trip to a library. They are more likely to check in with the Wikipedia community... than they are to ask a reference librarian for help" (Palfrey \& Gasser, 2008, p. 239).

It is problematic, however, to think about a generation made up of digital natives, because technology use is not an age-based concern, and expertise is definitely not conferred merely by being younger. Think for a minute about how you and the students at your institution use your mobile phones currently. Regardless of our ages, all of us have become more scheduled and more connected. What theorists say is a characteristic only of teens sounds familiar to those of us much older, too:

Sixty-three percent of teens say they text every day with people in their lives, and the typical teen sends about sixty text messages per day.... And now, with the widespread use of app-filled smartphones, the range of operations that teens can perform on the go has extended far beyond phone calls and texting.... The app mentality supports the belief that just as information, goods, and services are always and immediately available, so too are people. Scholars in the mobile communication field have dubbed such in-the-moment planning microcoordination. (Gardner \& Davis, 2013, p. 94)

Certainly, being a microcoordinator is just a fancier way of saying that all of us have become very attached to our phones. Google researchers compiled trillions of data points into eye-opening numbers about how closely our smartphones have become integrated into the rhythms of our everyday lives. Since 2010, the balance of Internetconnected device ownership, use, and dependence has shifted decisively away from place-bound computing and toward mobile Internet access.

Millennials? They're really attached. 87\% always have their smartphone at their side, day, and night. That little device by our sides is transforming our lives, whether we actively notice it or not. It's enabling new ways of doing and learning things. It's helping us discover new ideas and new businesses. It's helping us manage our to-dos, tackle our problems, and inspire our plans.

Mobile search behavior is a good reflection of our growing reliance: in many countries, including the
U.S., more searches take place on mobile devices than on computers. Mobile is quickly becoming our go-to.

Take the oft-quoted stat that we check our phones 150 times a day. Pair it with another that says we spend 177 minutes on our phones per day, and you get a pretty fascinating reality: mobile sessions that average a mere 1 minute and 10 seconds long, dozens and dozens of times per day. (Adams, Burkholder, \& Hamilton, 2015, p. 3)

Google's report is not intended to help educators to connect with our busy students. The report is meant to convince companies to spend advertising dollars to reach out to people who cannot seem to put their phones down.

However, we academics can learn from what Google has uncovered. Google calls most people's pattern of using their mobile phones "micro moments." All of us - not just members of a particular generation - use our phones to help us to make decisions in everyday situations like researching brands of toothpaste or comparing the quality of bedsheet sets, all while we are standing in the store aisle. We place calls on our phones when we want to move from the world of information to the world of people. Once we find the set of sheets we want, we might then call the customer-service line for the store in which we are standing and inquire about stock in other colors. We use our mobile devices to help us make decisions: Thai, Chinese, or barbecue for dinner?

Writing for Google, Adams et al. (2015, p. 6) advise companies to create small "snackable" pieces of content and interactions to which people can get access via different media, based on the choices (and devices) of the people who want to interact:

Here are three essential strategies that can help you win micromoments:

- Be There. You've got to anticipate the micromoments for users in your industry, and then commit to being there to help when those moments occur.

- Be Useful. You've got to be relevant to consumers' needs in the moment and connect people to the answers they are looking for.

- Be Quick. They're called micro-moments for a reason. Mobile users want to know, go, and buy swiftly. Your mobile experience has to be fast and frictionless.

We all engage in micromoments: we snack on information for a few seconds at a time, in the moment when needs or curiosity arise (Adams et al., 2015, p. 11). Because we are all adapting to the new technologies that we carry in our pockets, Losh (2014) says that we should avoid labeling one generation as the "so-called digital natives because it could naturalize cultural practices, further a colonial othering of the young, and oversimplify complicated questions about membership in a group."

In a significant sense, the terms "digital natives" and "digital generation" have been around longer than the connected-anytime-and-anyplace reality that they attempt to describe. Palfrey and Gasser (2008, p. 88) described 
digital natives as being tech experts, but place-bound by their desktop and laptop computers: "In the Internet context, images and stories of this sort are accessible from any Internet-ready device - a laptop sitting around the house or a cell phone with a decent Web browser (though, to be clear, most Digital Natives rarely access the Web through these devices today)."

Only a decade later, the caveat about how few people use their phones to go online seems almost quaint: today's 18-year-old college freshmen can barely remember a time when web access was not part of mobile phone technology, and people in their 30, 40, and $50 \mathrm{~s}$, and beyond have largely adapted to a world in which mobile computing is simply part of the fabric of everyday life, even if they themselves might not be the savviest participants in that mobile culture.

We can define the digital generation by saying that all people who use mobile technology on a daily basis for problem-solving, information-gathering, and social purposes - regardless of their age - are mobile learners. This definition allows for variation among the skill sets, background knowledge, and breadth of application that we all possess. This variation is a key to author's assertion that, as faculty members and learning designers, we should move away from a people-with-disabilities mindset when it comes to UDL, and we should move toward a people-with-mobiledevices mindset.

\section{GROWING BEYOND THE ROOTS OF UDL}

UDL began in the disability-advocacy community as a way of creating a more inclusive society, generally. "Recognition of disability as a civil right entails making sure that a person with a disability has access to the buildings, classrooms, and courts where those rights are learned and adjudicated" (Davidson, 2006, p. 126). UDL is an outgrowth of universal design ideas in the built environment - such as allocating parking spaces for drivers with disabilities (and keeping the shopping-cart corrals out of them).

UDL can often get mired in people's perceptions of a medical model that perceives disability as primarily a health issue, where disabilities are deficits in function that reside within the bodies of individuals themselves. This helps to explain why many people unconsciously associate negative emotions with their interactions with people who have disabilities (Stodden, Brown, \& Roberts, 2011). In contrast with a social model of disability, the disabling factor is seen to be in the environment. If a student in a wheelchair encounters a library building with stairs but not ramp, the disability is not inherent in the student - it is the design of the building that presents the challenge (Shakespeare, 2006). Because higher education is in transition between these two mental models of disability, my first radical reflection about UDL is to reframe it away from the concept of disability all together, and situate UDL in a narrative with which all faculty members and staffers are familiar - and one which has a much more neutral emotional valence: mobile learning.

In comparison with learners, only 15 years ago, students who come to college today are significantly more likely to require remedial instruction (Adams, 2015), more likely to have poor study habits and time-management challenges (College Board, 2015), and less likely to have significant time for study outside of the classroom. In North America, more college students than ever before are adult learners with family and job responsibilities - and precious little time for studying.

\section{It seems like it is just me and the computer}

In many institutions, there is near consensus among faculty members and campus leaders that the institution itself bears a responsibility to provide educational opportunities to the broadest possible audience of learners (Rapp \& Arndt, 2012). However, there is often a disconnection between that high-level responsibility and its operational implementation. More frequently, the challenge is left to be addressed by an institution's office of disability services, which provides non-mandated training courses on UDL and outreach techniques to individual faculty members.

A recent study of such training programs found that they increase faculty and staff confidence in working with students across the ability spectrum (Murray et al., 2011), but the adoption rate for UDL principles in North American colleges and universities continues to hover around $10 \%$ of faculty members in most reported research (cf. Murray et al., 2009), with the highest concentrations among faculty members in Education departments and colleges. Unlike the Americans with Disabilities Act in the United States, Canada does not yet have a nationwide set of laws requiring accommodations for people with disabilities. Starting in 2014, Roberta Thomson at McGill University in Montreal began a still-ongoing study in which she and her colleagues interviewed faculty members about their perceptions surrounding and adoption of UDL; her preliminary data suggest that even with training in UDL practices, only a small fraction of faculty members go on to implement UDL in a significant way. Dr. Thomson hypothesizes that this is due to the fact that most faculty members do not choose to attend UDL training, and, of those who do attend, a large percentage of faculty member report not having enough time to be able to accomplish a full UDL redevelopment of their existing course interactions (R. Thomson, personal communication, December 16, 2015).

Over the past three decades, especially, the role of faculty members in academia has become increasingly atomized (Braskamp \& Ory, 1994). Faculty members in 1985 were routinely expected to design their course structure, create their own individual syllabi, pull together their ancillary materials (which often took the form of photocopied "prof packs" of readings, overhead transparencies, and vendorproduced VHS tapes on topics of interest), teach their course sessions, grade student work, and hold office hours for communicating with students outside of class time.

Today, the model of course development worldwide has shifted to one of collaborative endeavors. Faculty members are still responsible for their content expertise. However, large swaths of what used to be the domain of individual faculty members has become the responsibility of the faculty as a whole (agreeing on common syllabi across course sections and even common reading lists, texts, and resources) or the responsibility of support staff 
(e.g., creation of video clips, multimedia content, and course content for use within a learning management system). In many cases, the design of a course's content and interactions is accomplished by a team of experts, of which the faculty member is only one part, in collaboration with an instructional designer, a media specialist, an IT coder, and others throughout the organizational chart of the institution. This has not saved faculty members any time, incidentally: faculty members in 1985 did not have e-mail or always on connections to their course environments to contend with.

This is why the author advocates focusing our UDL training on the people who actually put together the designed elements and interactions for courses. In author's own work with faculty members and support staff at colleges and universities across North America, this has often been the most difficult argument to make. Put in significant effort ahead of time, during the design or redesign of course interactions, in order to increase learner engagement, options for taking in information and options for control and choice in demonstrating knowledge and skills have been implemented. This effort will then pay the faculty member back many fold in the form of decreased student questions, decreased requests for accommodations, and a refocus away from the administrative minutiae of the course back to the interactions with students that motivated many of us to become faculty members in the first place. Adopting UDL also pays the institution back many fold in the form of increased student persistence, retention, and satisfaction.

Implementing such a change across an institution is no small undertaking. It requires leadership support and resources. As Candyce Rennegarbe at Tacoma Community College reports, the investment pays back an adopting institution handsomely:

By far, strong administrative support is the most important element. Our Vice President of Academic and Student Affairs has supported this project with funding and personal support since we started. He has used Achieving the Dream [program] funds and reserve funds; no major grant funding has been accessed to fund this project. We give release time to a faculty member to be the project manager in an affordable way to make sure there is sustained leadership.... We have also secured stipends for faculty and mentors and have involved the instructional research department from the beginning. We have a strong cross-disciplinary advisory team (Dean/VP of Instruction, Access Services, E-Learning, Developmental Studies, Professional Development, Student Services, Faculty), and strong support for building technology resources on campus. (Meyer et al., 2014, p. 169)

This approach - training those who actually do the development work on materials and interactions that UDL touches on - results in greater levels of adoption of UDL across the institution (Meyer et al., 2014, pp. 172-173). There is one more piece to the UDL-adoption puzzle: "if you build it, they will come" (Robinson, 1989). But will they know how to use it?

\section{FROM THREE DOMAINS TO "PLUS ONE"}

CAST has narrowed the tenets of UDL down to three brain networks that are addressed by well-designed learning interactions: the affective, recognition, and strategic networks (CAST, 2015). Each of these neural networks corresponds to one of the strategic areas of UDL:

- Affective networks: the why of learning. How learners get engaged and stay motivated. How they are challenged, excited, or interested. These are affective dimensions. Stimulate interest and motivation for learning.

- Recognition networks: the what of learning. How we gather facts and categorize what we see, hear, and read. Identifying letters, words, or an author's style are recognition tasks. Present information and content in different ways.

- Strategic networks: the how of learning. Planning and performing tasks. How we organize and express our ideas. Writing an essay and solving a math problem are strategic tasks. Differentiate the ways that students can express what they know (Meyer et al., 2014, p. 90).

In working with faculty members and support staffers, the author used to expand these domains into five areas of execution (Tobin, 2014). More recently, he simplifies them down to one rule for UDL: adopt a "plus one" mentality.

It can seem like a nearly insurmountable task to take a course that has been offered at an institution for years without UDL practices in it and retrofit the entire course. There are likely to be dozens - if not hundreds - of elements and interactions in the course that need to have alternative formats and options created for them, to say nothing of all of the motivation and encouragement that needs to be made explicit and added in to the design of the course materials. Looking at the project in this way is daunting. However, by adopting a "plus one" mind set, we can speedily chop down the work into parts that can we can work with. For instance, instead of creating all possible alternative formats for multimedia, select one consistently throughout the course. Create transcripts for video resources, but do not also create captions. Or vice versa; just be consistent.

Furthermore, identify where the course materials will get the greatest impact from the inclusion of UDL principles. Talk with the faculty members who teach the course and learn the parts of the course where students (a) always have questions; (b) always get things wrong on tests, quizzes, and assignments; and (c) always need things explained in more than one way. Those are the UDL hot spots in the course. Focus on efforts at adding UDL content and interactions around those hot spots for maximum impact. In their study on faculty willingness to adopt UDL principles, Lombardi and Murray seem almost surprised to come to a similar conclusion: doing the work up front reduces accommodation requests down the road.

[A]ctions associated with adopting inclusive instructional practices can be broken down into measurable steps. Ideally, this operationalization of U[niversal] D[esign] principles will help inform and encourage faculty to modify their instruction to be more inclusive and 
accessible to a wider range of learners, which will benefit all students, with and without disabilities. Further, some items... illustrated the inherent overlap between accommodating students and adopting the UD principles. (Lombardi \& Murray, 2011, p. 50)

Finally, draw a firm line for the institution regarding the creation of new content and interactions. As of an agreed-on date, mandate that all new materials meet UDL standards, to avoid continuing the need for retrofitting.

\section{CONCLUSIONS}

Sheryl Burghstahler and her team at the DO-IT Center at the University of Washington have put together a practical work flow for adopting UDL in higher education, which the author has summarized here:

1. Identify the application. Specify the product or environment to which you wish to apply UD.

2. Define the universe. Describe the overall population (e.g., users of service) and then describe the diverse characteristics of potential members of the population for which the application is designed.

3. Involve consumers. Consider and involve people with diverse characteristics in all phases of the development, implementation, and evaluation of the application.

4. Adopt guidelines or standards. Create or select existing UD guidelines or standards.

5. Apply guidelines or standards. Apply UD in concert with best practices within the field to the overall design of the application.

6. Plan for accommodations. Develop processes to address accommodation requests from individuals for whom the design of the application does not automatically provide access.

7. Train and support. Tailor and deliver ongoing training and support to stakeholders.

8. Evaluate. Include UD measures in periodic evaluations of the application. (DO-IT, 2015)

By providing UDL training to the people on campus who actually do the work of course design and content creation, we stand the greatest chance of achieving broad-based implementation across the institution.

A success story is the College STAR consortium in North Carolina (College STAR, 2015), composed of colleges and universities from across the state that used a federal grant in order to create a curriculum shared across campuses. Because the grant required the use of UDL, all of the participating campuses sent their support and design staff to common training sessions, and at present all of the courses and support mechanisms designed by the consortium are "born with UDL" as a matter of principle and practice.

This is the goal of UDL, after all: to reduce barriers to learning for everyone. the author argued that, while we should keep learners with disabilities always in mind, we can best serve the broadest audience of learners by making the case for UDL as a way to reach out to mobile learners as part of our anytime, anywhere learning initiatives, and that we should train our institutional support staff in good UDL practices, so that faculty members who wish to work on their courses will automatically be presented with UDL practices as "just the way we do things here."

Funding sources: None.

Author's contribution: TJT is the sole author and responsible for the submission of final version of the manuscript.

Conflict of interest: The author declares no conflict of interest.

\section{REFERENCES}

Adams, C. J. (2015, September 9). 2015 SAT, ACT scores suggest many students aren't college-ready. Education Week. Retrieved from http://www.edweek.org/ew/articles/2015/09/09/ 2015-sat-act-scores-suggest-many-students.html

Adams, L., Burkholder, E., \& Hamilton, K. (2015). Micromoments: Your guide to winning the shift to mobile. Mountain View, CA: Google. Retrieved from https://think.storage. googleapis.com/images/micromoments-guide-to-winning-shiftto-mobile-download.pdf

Benham, N. E. (1997). Faculty attitudes and knowledge regarding specific disabilities and the Americans with Disabilities Act. College Student Journal, 31, 124-129.

Bento, R. F. (1996). Faculty decision-making about "reasonable accommodations" for disabled college students. College Student Journal, 30(4), 494.

Bigaj, S. J., Shaw, S. F., \& McGuire, J. M. (1999). Communitytechnical college faculty willingness to use and self-reported use of accommodation strategies for students with learning disabilities. Journal for Vocational Special Needs Education, 21(2), 3-14.

Braskamp, L. A., \& Ory, J. C. (1994). Assessing faculty work: Enhancing individual and institutional performance. San Francisco, CA: Jossey-Bass.

CAST. (2014). UDL on campus: Universal design for learning in higher education - A guide. Retrieved from http://udloncampus. cast.org

CAST. (2015). About universal design for learning. Retrieved from http://www.cast.org/our-work/about-udl.html

CAST. (2016). UDL and assessment. UDL on campus. Retrieved from http://udloncampus.cast.org/page/assessment_UDL

Center for Universal Design. (2008). About UD: Universal design history. Raleigh, NC: North Carolina State University College of Design. Retrieved from https://www.ncsu.edu/ncsu/design/ cud/about_ud/udhistory.htm

Chen, B., Seilhamer, R., Bennett, L., \& Bauer, S. (2015, June 22). Students' mobile learning practices in higher education: A multiyear study. EDUCAUSE Review. Retrieved from http://er. educause.edu/articles/2015/6/students-mobile-learning-practicesin-higher-education-a-multiyear-study

College Board. (2015). 2015 college board program results, expanding access, challenging students, equipping educators. Retrieved from https://www.collegeboard.org/program-results 
College Supporting Transition, Access, and Retention [STAR]. (2015). About College STAR. Retrieved from https://www. collegestar.org/about

Connell, B. R., Jones, M., Mace, R., Mueller, J., Mullick, A., \& Ostroff, E. (1997). The principles of universal design. Raleigh, NC: North Carolina State University Center for Universal Design. Retrieved from http://www.ncsu.edu/ncsu/design/ cud/about_ud/udprinciplestext.htm

Cook, L., Rumrill, P. D., \& Tankersley, M. (2009). Priorities and understanding of faculty members regarding college students with disabilities. International Journal of Teaching and Learning in Higher Education, 21(1), 84-96.

Council for Exceptional Children. (2011). New guidelines for universal design for learning provide a roadmap for educators and educational publishers. Retrieved from https://web. archive.org/web/20120116035812/http://www.cec.sped.org/ $\mathrm{AM} /$ Template.cfm?Section $=$ Home\&CAT $=$ none\&CONTEN$\mathrm{TID}=10573 \&$ TEMPLATE $=/ \mathrm{CM} /$ ContentDisplay.cfm

Davidson, M. (2006). Universal design: The work of disability in an age of globalization. In L. J. Davis (Ed.), The disability studies reader (2nd ed., pp. 117-130). New York, NY: Routledge.

DO-IT (Disabilities, Opportunities, Internetworking, and Technology). (2015). Applications of universal design in postsecondary education. Seattle, WA: Center for Universal Design in Education, University of Washington. Retrieved from http://www. washington.edu/doit/programs/center-universal-design-education/ applications-universal-design-postsecondary-education

Dukes, L. (2014). Closed captioning matters: An examination of the use of captioning for all students. Paper presented at Postsecondary Training Institute Conference, Philadelphia, PA. Retrieved from https://slideplayer.com/slide/3720780/

Fichten, C. S. (1986). Self, other, and situation-referent automatic thoughts: Interaction between people who have a physical disability and those who do not. Cognitive Therapy and Research, 10(5), 571-587. doi:10.1007/BF01177820

Flaherty, C. (2017, September 15). A hill to retire on? Inside Higher $E d$. Retrieved from https://www.insidehighered. com/news/2017/09/15/atmospheric-scientist-illinois-leave-afterrefusing-provide-lecture-slides-student

Fonosch, G., \& Schwab, L. O. (1981). Attitudes of selected university faculty members toward disabled students. Journal of College Student Personnel, 22(3), 229-235.

Frijda, N. H. (1986). The emotions. Studies in emotion and social interaction series. Cambridge, UK: Cambridge University Press.

Gardner, H., \& Davis, K. (2013). The app generation: How Today's youth navigate identity, intimacy, and imagination in a digital world. New Haven, CT: Yale University Press.

Gaylord, V., Johnson, D. R., Lehr, C. A., Bremer, C. D., \& Hasazi, S. (Eds.). (2004). Impact: Feature issue on achieving secondary education and transition results for students with disabilities(Vol. 16, no. 3). Minneapolis, MI: University of Minnesota, Institute on Community Integration. Retrieved from http://ici.umn.edu/products/impact/163

Houck, C. K., Asselin, S. B., Troutman, G. C., \& Arrington, J. M. (1992). Students with learning disabilities in the university environment: A study of faculty and student perceptions. Journal of Learning Disabilities, 25(10), 678-6844. doi:10. 1177/002221949202501008
Institute for Human Centered Design. (2017). History of universal design. Boston, MA: IHCD. Retrieved from https://web. archive.org/web/20170929034659/http://www.humancentered design.org/universal-design/history-universal-design

Jukes, I., McCain, T., \& Crockett, L. (2010). Understanding the digital generation: Teaching and learning in the new digital landscape. Toronto, ON: Corwin Publishers.

Lombardi, A. R., \& Murray, C. (2011). Measuring university faculty attitudes toward disability: Willingness to accommodate and adopt universal design principles. Journal of Vocational Rehabilitation, 34(1), 43-56. doi:10.3233/JVR2010-0533

Lombardi, A. R., Murray, C., \& Gerdes, H. (2011). College faculty members and inclusive instruction: Self-reported attitudes and actions pertaining to universal design for learning. Journal of Diversity in Higher Education, 4(4), 250-261. doi:10.1037/ a0024961

Losh, E. (2014, June 14). Education's war on millennials: Why everyone is failing the "digital generation". Salon. Retrieved from http://www.salon.com/2014/06/14/educations_war_on_ millennials_why_everyone_is_failing_the_digital_generation/

Mason, K. C. (2014, August 25). Colleges adjust to new reality that more students juggle work, family. PBS NewsHour. Retrieved from http://www.pbs.org/newshour/updates/colleges-adjust-tonew-reality-that-students-juggle-work-family-more/

Meyer, A., Rose, D., \& Gordon, D. (2014). Universal design for learning: Theory and practice. Wakefield, MA: CAST Professional Publishing.

Murray, C., Lombardi, A., \& Wren, C. (2011). The effects of disability-focused training on the attitudes and perceptions of university staff. Remedial and Special Education, 32(4), 290-300. doi:10.1177/0741932510362188

Murray, C., Lombardi, A., Wren, C. T., \& Keys, C. (2009). Associations between prior disability-focused training and disability-related attitudes and perceptions among university faculty. Learning Disability Quarterly, 32(2), 87-100. doi: $10.2307 / 27740359$

Nelson, J., Dodd, J., \& Smith, D. (1990). Faculty willingness to accommodate students with learning disabilities. Journal of Learning Disabilities, 23(3), 185-189. doi:10.1177/ 002221949002300309

Office of Special Education Programs [OSEP]. (2004). U.S. Department of Education-funded centers that support UDL. Tool Kit on Universal Design for Learning. Washington, DC: U.S. Department of Education. Retrieved from https:// osepideasthatwork.org/federal-resources-stakeholders/tool-kits/ tool-kit-universal-design-learning-udl/centers

Palfrey, J., \& Gasser, U. (2008). Born digital: Understanding the first generation of digital natives. New York, NY: Basic Books.

Rapp, W. H., \& Arndt, K. (2012). Teaching everyone: An introduction to inclusive education. Baltimore, MD: Brookes Publishing.

Robinson, P. A. (1989). Field of dreams. Los Angeles, CA: Universal Pictures.

Schwab, C. (2015). The innovator of universal design, Mr. Ron Mace explained differences between universal design and barrier free in 1989. Retrieved from http://www.accessiblehealthhome. com/2015/10/09/the-father-of-universal-design-mr-ron-maceexplained-differences-between-universal-design-and-barrierfree-in-1989/ 
Shakespeare, T. (2006). The social model of disability. In L. J. Davis (Ed.), The disability studies reader (2nd ed., pp. 197-204). New York, NY: Routledge.

Stodden, R. A., Brown, S. E., \& Roberts, K. (2011). Disabilityfriendly university environments: Conducting a climate assessment. New Directions for Higher Education, 1(154), 83-92. doi: $10.1002 /$ he. 437

Tobin, T. J. (2014). Increase online student retention with universal design for learning. Quarterly Review of Distance Education, 15(3), 13-24. Retrieved from http://www.engl.duq.edu/servus/ cv/QRDE.UDL.Article.pdf
Tobin, T. J., \& Behling, K. T. (2018). Reach everyone, teach everyone: Universal design for learning in higher education. Morgantown, WV: West Virginia University Press.

Tomlinson, C. A. (1999). Mapping a route toward a differentiated instruction. Educational Leadership, 57(1), 12.

Zhang, D., Landmark, L., Reber, A., Hsu, H., Kwok, O., \& Benz, M. (2010). University faculty knowledge, beliefs, and practices in providing reasonable accommodations to students with disabilities. Remedial and Special Education, 31(4), 276-286. doi:10.1177/0741932509338348 